\begin{tabular}{|c|c|c|}
\hline 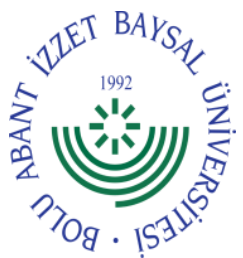 & $\begin{array}{l}\text { International Journal of Agriculture and Wildlife } \\
\qquad \text { Science } \\
\text { http://dergipark.org.tr/ijaws }\end{array}$ & 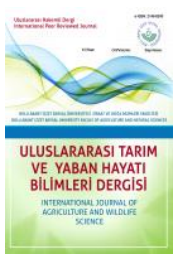 \\
\hline
\end{tabular}

Research Article

\title{
Heavy Metal Accumulations in Some Terrestrial Endemic and Non-endemic Plants in Mine Sites (Elazığ/Turkey)
}

\author{
Dudu Duygu Kılıç* (D)， Gülfiye Ortakçı \\ Department Biology, Faculty of Arts and Science, Amasya University, Amasya, Turkey
}

Received: $07.10 .2020 \quad$ Accepted: 10.02 .2021

\begin{abstract}
Keywords:
Hyperaccumulator, hytoremediation, mining, heavy metal, endemic plants, Elaziığ Maden
\end{abstract}

*Corresponding author duygu.kilic@amasya.edu.tr

\begin{abstract}
The aim of our study is to determine the hyperaccumulatory properties by examining the heavy metal accumulation ( $\mathrm{Co}, \mathrm{Ni}, \mathrm{Fe})$ in endemic Anchusa leptophlla subsp. tomentosa, Alyssum pateri subsp. pateri, Glaucium acutidentatum and non endemic Erysimum uncinatifolium species collected from a copper mining area in Elazığ Maden district. All species collected are hyperaccumulator according to their Bioconcentration Factor (BCF) values of Co element. According to NiBCF and FeBCF values, A. leptophlla and E. uncinatifolium species were found to be hyperacumulators. According to Transfer Factor (TF) value, it is determined that Co element can be transported upper organs in A. leptophlla, A. pateri species, whereas $\mathrm{Ni}$ and Fe elements in A. leptophlla, A. pateri, E. uncinatifolium species. Among the species examined, the CoEF values for A. leptophlla and NiEF values $(E F>1)$ in all species are found to be higher than 1 according to the Enrichment Factor (EF). It can be said that the Ni accumulation capacities of all species are higher. In the study, soils samples taken from sampling area according to the Geoaccumulation index (Igeo) were found to be moderately contaminated in by Co and not so polluted by Fe.
\end{abstract}

\section{Elazığ (Maden) Maden Sahasındaki Bazı Karasal Endemik ve Endemik Olmayan Bitkilerde Ağır Metal (Co, Ni, Fe) Biyoakümülasyonları}

Anahtar kelimeler:
Hiperakümülatör,
fitoremediasyon,
madencilik, ağir metal,
endemik bitkiler, Elaziğ
Maden

\begin{abstract}
Özet.
Çalışmamızın amacı, Elazığ Maden ilçesinde bir bakır madeni sahasından toplanan endemik Anchusa leptophlla subsp. tomentosa, Alyssum pateri subsp. pateri, Glaucium acutidentatum ve endemik olmayan Erysimum uncinatifolium türlerindeki ağır metal birikimini (Co, $\mathrm{Ni}, \mathrm{Fe})$ inceleyerek hiperakümülasyon özelliklerini belirlemektir. Toplanan tüm türler, Co elementinin Biyokonsantrasyon Faktörü (BCF) değerlerine göre hiperakümülatördür. NiBCF ve FeBCF değerlerine göre $A$. leptophlla ve $E$. uncinatifolium türlerinin hiperakümülatör olduğu görülmüştür. Transfer Faktör (TF) değerine göre A. leptophlla, A. pateri türlerinde Co elementinin üst organlara, A. leptophlla, A. pateri, E. uncinatifolium türlerinde $\mathrm{Ni}$ ve $\mathrm{Fe}$ elementlerinin üst organlara taşınabildiği belirlenmiştir. Araştırılan türler arasında zenginleştirme faktörü (EF) değerine göre $\mathrm{A}$. leptophlla'daki CoEF ve tüm türlerde $\mathrm{Ni} \mathrm{EF}$ değeri (EF> 1) 1'den yüksek bulunmuştur. Tüm türlerin Ni biriktirme kapasitelerinin daha yüksek olduğu söylenebilir. Bu çalışmada, Jeobirikim İndeksi $\left(I_{\text {geo }}\right)^{\prime}$ ne göre örnekleme alanından alınan toprak örneklerinin Co tarafından orta derecede kirlendiği ve Fe ile çok fazla kirlenmediği bulunmuştur.
\end{abstract}


Kılıç and Ortakçı, Heavy Metal Accumulations in Some Terrestrial Endemic and Non-endemic Plants in Mine Sites (Elazığ/Turkey)

\section{INTRODUCTION}

One of the sectors that has importance to give shape civilizations from past to present is mining. Countries with bigger economies are generally those with high underground wealth. It can be said that there is a correct ratio between the development level of countries and the mining sector. In recent years, with the rapid population increase, an increase in soil pollution is observed as a result of mining industry and industrial activities. In Turkey; boron salts, barite, gypsum, meerschaum, marble, diatomite, perlite, magnesite, limestone, pumice, sodium sulfate, quartz-quartzite, lignite, feldspar, rock salt, silica sand, gold, trona and emery stone are among the important minerals (Borand, 2012).

According to mining specialization commission report (2001) data, Turkey, which ranks $28^{\text {th }}$ among 132 countries in the world in terms of total mineral production value and ranks $10^{\text {th }}$ in terms of mine diversity. Turkey is rich in energy raw materials such as industrial raw materials which are at the first, some metallic minerals, lignite and geothermal (Aktan et. al. 2017). Heavy metal pollution is one the most important problems of today. On the other hand heavy metal pollution is increasing human population and depending on this population, industry, traffic and agriculture etc. activities are causes heavy metal pollution. Heavy metals cause accumulation in the human body through the food chain and cause many diseases, especially cancer. Prospecting activities are the top of the reasons that cause heavy metal pollution.

Physical, chemical and biological methods are used to rehabilitate soils and water resources contaminated with heavy metal. Physical and chemical methods include both expensive and reconstructive methods (Danh, 2009, Salt et al., 1995).Green breeding (phytoremediation) technology, which is cost-effective and environmentally friendly, has been used in recent years. Phytoremediation is an effective method to improve contaminated natural environments (Garbisu et al., 2002). Hyperacumulator plants are extraordinary plants that accumulate certain metals in living tissues at levels that are hundreds or thousands of times higher than most plants (Reeves, 2003, Van der Ent et al., 2016, Reeves et al., 2018). These plants accumulate metals in their shoots and show extreme tolerance to metals (McGrath et al., 2001).Another requirement for classification of a hyperacumulator plant is that concentrations in plants should be 10 to 500 times higher than plants grown in uncontaminated environments (Yanqun et al., 2005). It is known from the literature that there are more than 400 hyperaccumulatory plant species. It should be preferred that the hyperaccumulator plants are an element of the natural vegetation in that environment (Yang et al., 2004).

Iron, which is responsible for the synthesis of chlorophyll pigments, is an essential nutrient element that causes disruption photosynthesis in case of deficiency. The toxicity of iron is not very common. Generally, the toxicity effect occurs when some plants secrete root secretions that lower soil $\mathrm{pH}$, resulting in increased iron uptake (Becker and Asch, 2005; Yerli et al.,2020). Iron, which has a toxic effect, causes burns on leaves and stunted roots and stems (Seven et al., 2008). Cobalt is a heavy metal that is similar in behavior to nickel and iron and forms 0.001 per cent of the earth's crust (Seven et al., 2008; Yerli et al.,2020). While cobalt is an important component for humans, animals and prokaryotes, its role in plants is not fully understood (Khan and Khan, 2010). Cobalt studies with increasing doses have shown that the rise in dose negatively affected biomass and yield (Khan and Siddhu, 2006). While nickel is abundant in the world, it can be found in trace amounts in the soil. Large concentrations can be harmful to orgasms (Cempel and Nikel, 2006). The absolute importance of nickel, a plant nutrient, has not been thoroughly clarified for plants. However, since nickel is the building material of enzymes such as urease and hydrogenase in the plant, when there is a nickel deficiency, the plants cannot benefit from urea fertilizers (Kacar and Katkat, 2006).

The aim of our study is to determine the hyperaccumulatory properties by examining the heavy metal accumulation (Co, $\mathrm{Ni}$, Fe) concentrations of endemic Anchusa leptophlla Roemer \& Schultes subsp. tomentosa (Boiss.) Chamb., Alyssum pateri Nyar subsp. pateri, Glaucium acutidentatum Hausskn.\& Bornm and nonendemic Erysimum uncinatifolium Boiss. species collected from the copper mining area in Elazığ Maden district.

\section{MATERIAL AND METHOD}

This study was carried out in the Maden district of Elazığ Province in the Eastern Anatolia region. The average height of the research area from the sea is $1054 \mathrm{~m}$, and the mine area is between $38^{\circ} 23^{\prime} 13.6^{\prime \prime} \mathrm{N}$ $39^{\circ} 39^{\prime} 50.9^{\prime \prime}$ E coordinates. The study area is located in the Iran-Turan Plant Geography Region and is in B7 area according to Davis's "Grid system". The B7 area, which includes our study area, is the richest area in terms of endemism after the Mediterranean Region. Copper mine in the Maden is one of the most important mine in Turkey and it has been mining more than 4.000 years (Seeliger et al., 1985, Çakılcıoğlu and Civelek, 2011). The 
Kılıç and Ortakçı, Heavy Metal Accumulations in Some Terrestrial Endemic and Non-endemic Plants in Mine Sites (Elazığ/Turkey)

most common metals in Maden district are copper, lead, zinc, iron and silver (Demir, 2018). Eastern Anatolia is the coldest region of Turkey (Şengün, 2007). The annual average temperature is $4.3^{\circ} \mathrm{C}$, the annual average precipitation is $509.7 \mathrm{~mm}$, the lowest average temperature is $-7.4{ }^{\circ} \mathrm{C}$ (Çakılcıoğlu and Civelek, 2011). In the research area, 4 different parcels of $25 * 25 \mathrm{~m}^{2}$ size were determined in areas where plants are dense and at least 5 samples were collected from the parcels (Figure 1).

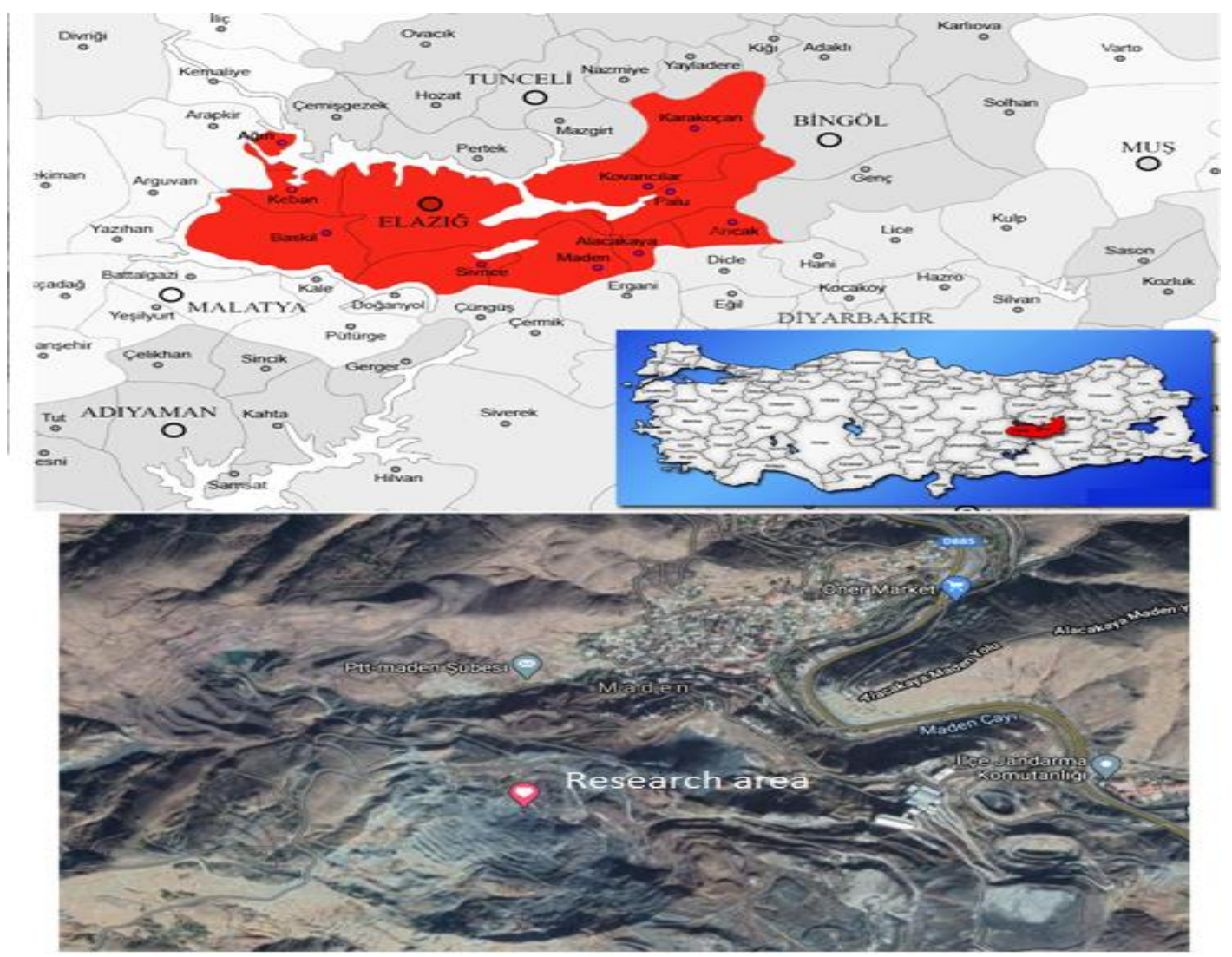

Figure 1. Image of Elazığ Maden district mining area.

Şekil 1. Elazığ Maden ilçesi maden sahası görüntüsü.

\section{Heavy Metal Analysis}

Sterile plastic gloves were used to prevent contamination during the collection of plant samples. Plant samples belonging to healthy individuals were collected from each parcel and exact identification of the samples were made. Soil samples were taken from a depth of $15 \mathrm{~cm}$ after the rash on the soil surface was cleaned. Some of the plant samples carefully collected from the study areas were pressed and made into herbarium samples. Collected plant samples were washed with distilled water. The washed plant samples were dried in the drying-oven at $70{ }^{\circ} \mathrm{C}$ and then ground and prepared for analysis. Samples for heavy metal analysis were added with $10 \mathrm{ml}$ of concentrated nitric acid $\left(\mathrm{HNO}_{3}\right)$ and $2 \mathrm{ml}$ of hydrogen peroxide $\left(\mathrm{H}_{2} \mathrm{O}_{2}\right)$ and burned. The amounts of heavy metal accumulated in soil and plant organs were determined by three replicates (ICPOES) and the obtained data were evaluated. All data were analyzed using SPSS (18.00) statistical package program.

\section{Calculations}

\section{Soil Heavy Metal Enrichment Factor (Enrichment Factor, EF)}

Is an indicator used in the evaluation of metal accumulation in soils. The enrichment factor is one of the preferred methods for evaluating of environment over time and calculating human contribution in metal pollution. The following formula is used to calculate the enrichment factor (Buat-Menard and Chesselet, 1979).

$$
\text { Enrichment Factor }(\mathrm{EF})=\frac{(\mathrm{Cf} / \mathrm{Cref}) \text { sample }}{(\mathrm{Bn} / \text { Bref }) \text { reference }}
$$


Kılıç and Ortakçı, Heavy Metal Accumulations in Some Terrestrial Endemic and Non-endemic Plants in Mine Sites (Elazığ/Turkey)

In the formula, Cf; the value of the element in the analyzed sample Cref: The value of the reference element in the analyzed sample Bn; Average value of the element in soil according to Brooks (1972) Bref; According to Brooks (1972), it was used as the average value of the reference element in the soil. (In this study Mn is used as reference element.)

\section{Geoaccumulation Index (Igeo)}

Is an indicator used to determine the level of metal contamination in the soil by comparing current element values with pre-industrial values. It was proposed by Müller (1969). The following formula is used to calculate the geoaccumulation index.

$$
\text { Geoaccumulation Index }\left(\mathrm{I}_{\mathrm{geo}}\right)=\log _{2} \frac{\mathrm{Cn}}{1,5 \times \mathrm{Bn}}
$$

$\mathrm{Cn}$; Heavy metal concentration in the studied sample, Bn; It is expressed as the average value of $\mathrm{n}$ metal in soil (Brooks, 1972).

\section{Bioconcentration Factor (BCF)}

It is evaluated with BCF and TF values in the selection of plants to be grown for phytoremediation. This value has been used to identify plants to be used for phytoextraction. It is formulated based on the ratio between total heavy metal concentration present in the plant and soil (Ladislas et al., 2012).

$$
\mathrm{BCF}=\frac{\text { Heavy metal concentration in the plant }}{\text { Soil heavy metal concentration }}
$$

\section{Transfer Factor (TF)}

Another indicator that expresses the metal uptake measure of plants is Transfer Factor. The transfer factor is an indicator of the movement of heavy metals from the root to the upper organs. In the calculation of this factor, the proportion of metal concentrations in the shoot of plants is proportional to the root metal concentration, and it was used to give an idea about the ability to transfer heavy metal in the plant (Alaribe and Agamuthu, 2015; Badr et al., 2012, Padmavathiamma and Li, 2007).

$$
\text { Transfer Factor }(\mathrm{TF})=\frac{\text { Shoot heavy metal concentration }}{\text { Root heavy metal concentration }}
$$

TF $>1$ is always essential in over-accumulating (hyperacumulator) plants. TF is used to assess the plant's capacity to transport heavy metal from the roots to the upper organs.

\section{RESULTS AND DISCUSSION}

Average Co accumulation in species were found as $E$. uncinatifolium $\left(279.408 \pm 0.596 \mathrm{mg} \mathrm{kg} \mathrm{mg}^{-1}\right)>\mathrm{G}$. acutidentatum $\left(148.860 \pm 0.099 \mathrm{mg} \mathrm{kg}^{-1}\right)$, and $A$. pateri $\left(129.700 \pm 103.133 \mathrm{mg} \mathrm{kg}^{-1}\right)>$ A. leptophlla (94.277 \pm $0.399 \mathrm{mg} \mathrm{kg}^{-1}$ ) respctiveley. E. uncinatifolium species accumulated highest Co in root (173.344 $\left.\pm 0.345 \mathrm{mg} \mathrm{kg}{ }^{-1}\right)$ while the lowest Co $\left(95.246 \pm 0.884 \mathrm{mg} \mathrm{kg}^{-1}\right)$ in the stem. G. acutidentatum species accumulated the most Co in the root $\left(78.643 \pm 0.052 \mathrm{mg} \mathrm{kg}^{-1}\right)$, while lowest in the stem $\left(25.719 \pm 0.086 \mathrm{mg} \mathrm{kg}^{-1}\right)$. The least amount of Co accumulation was in the root and stem of the $A$. leptophlla species. The amount of Co in soil varies between $9.206 \pm 0.043 \mathrm{mg} \mathrm{kg}^{-1}$ and $64.006 \pm 0.146 \mathrm{mg} \mathrm{kg}^{-1}$ (Figure 2).

$\mathrm{Ni}$ value of the plants was found to be . uncinatifolium $\left(5597.461 \pm 132.715 \mathrm{mg} \mathrm{kg}^{-1}\right)>$ A. pateri $(2632.630 \pm$ $2487.592 \mathrm{mg} \mathrm{kg}^{-1}$ ) >A. leptophlla $2292.835 \pm 1.860 \mathrm{mg} \mathrm{kg}^{-1}>$ G. acutidentatum $\left(2205.706 \pm 11.390 \mathrm{mg} \mathrm{kg}^{-1}\right)$.

Ni element value was found high in the leaves and roots of plants. This value is low in the stems of plants. Nickel accumulated in the highest at leaf (5219.796 $\left.\pm 136.095 \mathrm{mg} \mathrm{kg}^{-1}\right)$ of $E$. uncinatifolium species, while $A$. paterium accumulated in the highest at root $\left(1626.771 \pm 2487.747 \mathrm{mg} \mathrm{kg}^{-1}\right)$. Nickel value in the soil varies between $1982.830 \mathrm{mg} \mathrm{kg}^{-1}$ - 5597. $461 \mathrm{mg} \mathrm{kg}^{-1}$.

Fe accumulations of the species were found as $E$. uncinatifolium $42.106 \pm 0.338 \mathrm{mg} \mathrm{kg}^{-1}>$ A. pateri $8.075 \pm$ $6.080 \mathrm{mg} \mathrm{kg}^{-1}>$ G. acutidentatum $6.386 \pm 0.004 \mathrm{mg} \mathrm{kg}^{-1}>$ A. leptophlla $5.516 \pm 0.002 \mathrm{mg} \mathrm{kg}^{-1}$, respectively. Fe element was found higher in root and leaf in investigated species. Fe values in the soil vary between $4.424 \pm$ $0.059 \mathrm{mg} \mathrm{kg}^{-1}$ and $12.481 \pm 0.023 \mathrm{mg} \mathrm{kg}^{-1}$ (Figure 2). 

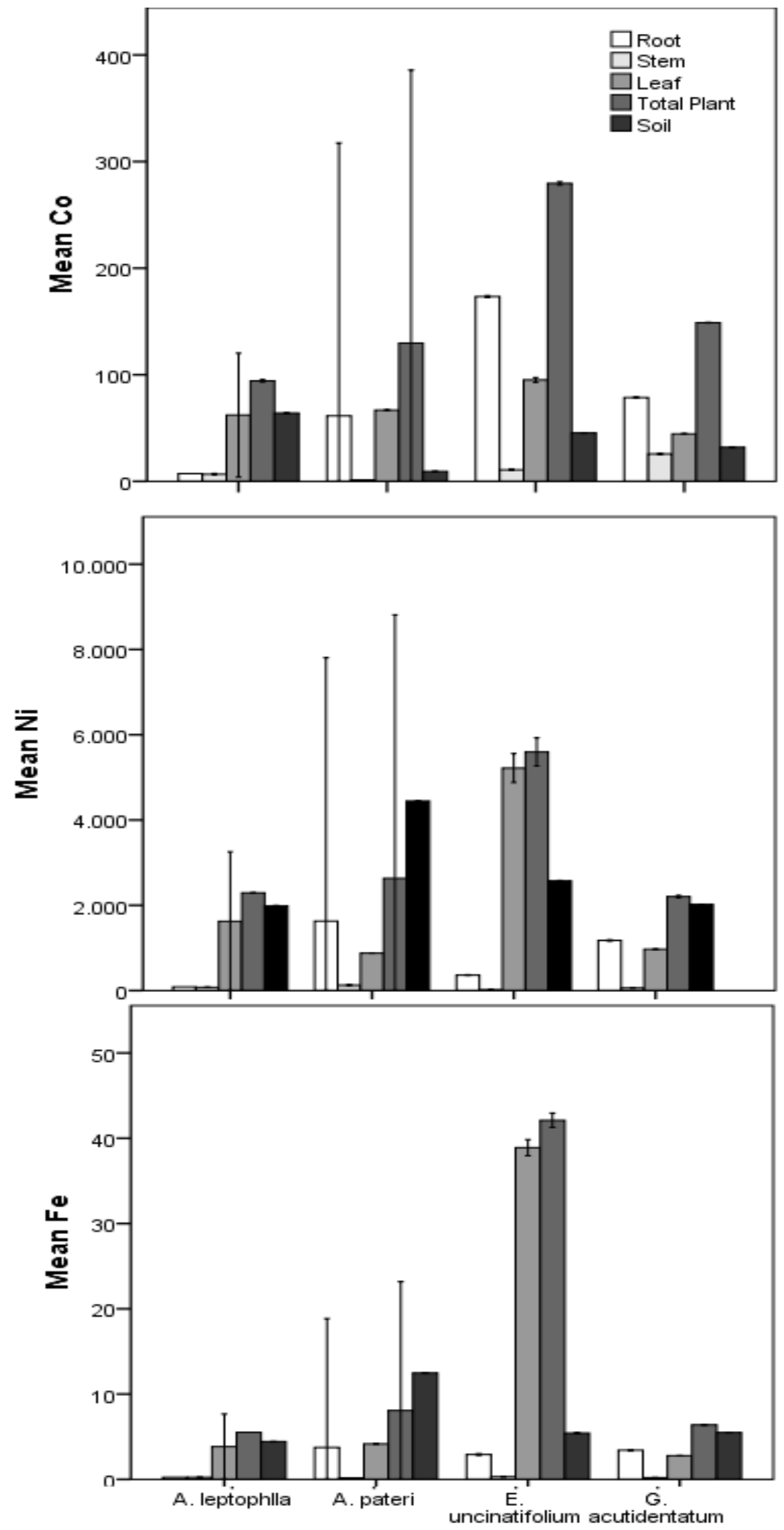

Figure 2. $\mathrm{Co}, \mathrm{Ni}$, Fe concentration in species, plant organs and soil $\left(\mathrm{mg} \mathrm{kg}^{-1}\right)$.

Şekil 2. Türlerde, bitki organlarında ve toprakta Co, $\mathrm{Ni}$, Fe konsantrasyonu $\left(\mathrm{mg} \mathrm{kg}^{-1}\right)$. 
Kılıç and Ortakçı, Heavy Metal Accumulations in Some Terrestrial Endemic and Non-endemic Plants in Mine Sites (Elazığ/Turkey)

Table 1. According to various researchers, the limit values of co in plants and soil and tukey's hsd test (means followed by the same letter are not significantly different at the 0.05 level /the first value is the lower limit of the contaminated value, the second value is the upper limit).

Çizelge 1. Çeşitli araştırmacılara göre bitkilerde ve toprakta Co limit değerleri ve Tukey hsd testi (aynı harfin takip ettiği araçlar 0.05 düzeyinde önemli ölçüde farklı değildir / ilk değer kontamine değerin alt sınırıdır, ikinci değer üst sınırdır).

\begin{tabular}{|c|c|c|c|c|}
\hline Species & $\begin{array}{l}\text { Co } \\
\mathbf{m g ~ k g}^{-1}\end{array}$ & $\begin{array}{l}\text { Adriano } \\
(1986)\end{array}$ & $\begin{array}{l}\text { Tok } \\
\text { (1997) }\end{array}$ & $\begin{array}{l}\text { Özbek et al. } \\
(1995)\end{array}$ \\
\hline A. leptophlla & $94.27 \pm 00.3 b$ & \multirow{4}{*}{$>1000$} & \multirow{4}{*}{$0.02-0.5$} & \multirow{4}{*}{$0.02-0.5$} \\
\hline A. pateri & $129.7 \pm 103.1 b$ & & & \\
\hline E.uncinatifolium & $279.408 \pm 0.59 a$ & & & \\
\hline \multirow[t]{2}{*}{ G. acutidentatum } & $148.860 \pm 0.09 b$ & & & \\
\hline & & $\begin{array}{l}\text { Alloway } \\
\text { (1995) }\end{array}$ & $\begin{array}{l}\text { Özbek et al. } \\
(1995)\end{array}$ & $\begin{array}{c}\text { TKKY }^{*} \\
(\mathrm{Ph}>6)(2001)\end{array}$ \\
\hline Soil & $9.206-64.006$ & $10-15$ & $1-40$ & 80 \\
\hline
\end{tabular}

Average Co contents of the species have values far above the limits determined by Tok (1997) and Özbek et al. (1995). In a study conducted by. Rose et al. (1979), it was stated that Co content was $1-110 \mathrm{mg} \mathrm{kg}^{-1} \mathrm{in}$ magmatic rocks, $0.1-0.3 \mathrm{mg} \mathrm{kg}^{-1}$ in sedimentary rocks, and these values could be $10 \mathrm{mg} \mathrm{kg}^{-1}$ on average in soils. In Elazığ Maden District mining area, Co value in plants was above the limits determined by the researchers, and the soil Co value was found within the limits (Kırat, 2017; Çeliktaş, 2020) (Table 1).

The cobalt values of the species belonging to the genus Alyssum in the Adana chromium mining area and Erysimum in the Malatya mining area are lower than the cobalt values of the species in our study (Table 1). With an average of $25 \mathrm{mg} \mathrm{ton}^{-1}$ on earth, cobalt is in the group of the least frequently found elements. The estimated reserve is $5.7 \times 106$ ton (Sibley, 2011). The distribution of nickel and cobalt in the earth crust is similar. Cobalt is essential for plants which fix atmospheric nitrogen. Co concentrations in uncontaminated areas have been reported between 2.0 and $27.0 \mathrm{mg} \mathrm{kg}^{-1}$ for soil and 0.03 to $1.0 \mathrm{mg} \mathrm{kg}^{-1}$ for plants on a dry weight basis (Kabata - Pendias and Pendias, 2001). Maximum cobalt levels in agricultural lands have been suggested in the range of 20-50 mg kg-1 (Jones, 1997).

In the study conducted in the Congo Katanga mining area, 0-1429 $\mathrm{ug} \mathrm{g}^{-1}$ Co (Malaisse et al., 1999) was found in the dry weight content of the plants, and in the soil this value was $2 \mathrm{mg} \mathrm{kg}^{-1}$ to $22.467 \mathrm{mg} \mathrm{kg}^{-1}$ (Pourret et al., 2016). In our study, this value is quite low compared to Katanga values. These concentrations are related to high metallic and metalloid content in Katanga soils (Pourret et al., 2016).

Table 2. According to various researchers, the limit values of ni in plants and soil and tukey's hsd test (means followed by the same letter are not significantly different at the 0.05 level /the first value is the lower limit of the contaminated value, the second value is the upper limit).

Çizelge 2. Çeşitli araştırmacılara göre bitkilerde ve toprakta Ni limit değerleri ve Tukey hsd testi (aynı harfin takip ettiği araçlar 0.05 düzeyinde önemli ölçüde farklı değildir / ilk değer kontamine değerin alt sınırıdır, ikinci değer üst sınırdır.).

\begin{tabular}{|c|c|c|c|c|}
\hline Species & $\begin{array}{l}\mathrm{Ni} \\
\mathrm{mg} \mathrm{kg}^{-1}\end{array}$ & $\begin{array}{c}\text { Brooks ve } \\
\text { Radford } \\
(1978)\end{array}$ & $\begin{array}{c}\text { Adriaono } \\
(1986)\end{array}$ & $\begin{array}{l}\text { Allen } \\
\text { (1989) }\end{array}$ \\
\hline A. leptophlla & $2292.8 \pm 1,8 b$ & \multirow{4}{*}{$5-700$} & \multirow{4}{*}{$>0.024$} & \multirow{4}{*}{$0.5-5$} \\
\hline A. pateri & $2632.6 \pm 2487 b$ & & & \\
\hline E. uncinatifolium & $5597.46 \pm 132 b$ & & & \\
\hline \multirow[t]{2}{*}{ G. acutidentatum } & $2205.706 \pm 11 a$ & & & \\
\hline & & Alloway (1995) & $\begin{array}{c}\text { Özbek } \\
\text { et.al. (1995) }\end{array}$ & $\begin{array}{l}\text { TKKY } \\
(P h>6) \\
(2001)\end{array}$ \\
\hline Soil & $1982.83-4444.65$ & $26-1000$ & $100-5000$ & 75 \\
\hline
\end{tabular}


Kılıç and Ortakçı, Heavy Metal Accumulations in Some Terrestrial Endemic and Non-endemic Plants in Mine Sites (Elazığ/Turkey)

The nickel element needed by the plant is required at the germination stage of the seed. In addition, nickel is participated in the structure of the urease enzyme (Hussain et al., 2013, Seregin and Kozhevnikova, 2006). According to the researches, nickel is a useful element for nitrogen metabolism in legumes and an important element for the metabolism of other plants (Kacar and Katkat, 2010). Nickel is a highly mobile element in the natural environment. It is easily absorbed by plants in proportion to the soil concentration until it reaches its toxic level (Guo and Marschner, 1995).

While the permissible limit in the soil is $35 \mathrm{mg} \mathrm{kg}^{-1}$ according to nickel values, it is $10 \mathrm{mg} \mathrm{kg}^{-1}$ in the plant. In the species we investigated, nickel value (2205.706 $\left.\pm 11.390-5597.461 \pm 132.715 \mathrm{mg} \mathrm{kg}^{-1}\right)$ varies between. The highest nickel accumulation was determined in $E$. uncinatifolium (Table 2).

In a study on plants grown on contaminated soils due to chromite mining in the Shangla region of Pakistan, Nawab et al. (2015) found the nickel concentration between 6 and $388 \mathrm{mg} \mathrm{kg}{ }^{-1}$. In our study, it was observed that the nickel concentration in plant species was much higher than the reference area. Ni concentrations in the investigated plant species were found to be much higher than those growing in mafic and ultramafic rocks in the Mingora and Kabal regions and Pakistan (Shah et al., 2010).

In the soil, Ni concentration was found between $1982.830 \pm 24.277-4444.650 \pm 16.081 \mathrm{mg} \mathrm{kg}^{-1}$. Shah et al. (2010), in soil found $\mathrm{Ni}$ concentrations on average $637 \mathrm{mg} \mathrm{kg}^{-1}$. This value is considerably lower than our field of study. It was determined that the soil around the Kütahya Tunçbilek Thermal power plant is 16.6 to $2385 \mathrm{mg}$ $\mathrm{kg}^{-1}$. It was determined that the highest nickel concentration (15-33.2 $\mathrm{mg} \mathrm{kg}^{-1}$ ) among the plants in Elazığ Keban "Derebacı Gallery" mining area (Bakırdede et al., 2016).

According to Allen (1989), the concentration of nickel that should be present in plants is $0.5-5 \mathrm{mg} \mathrm{kg}^{-1}$ (Demirezen, 2002). Kabata- Pendias and Pendias (1992), report the optimum Ni limit in plants as $0.02-5 \mathrm{mg} k \mathrm{~kg}$ ${ }^{1}$. Brooks and Radford (1978), stated that this value exceeds approximately $50 \mathrm{mg} \mathrm{kg}^{-1}$ in serpentine lands and is over $1000 \mathrm{mg} \mathrm{kg}^{-1}$ in hyperacumulator plants.

In the study conducted in Adana Crom mine, Ni amount, Alyssum alyssoides $878.28 \mathrm{mg} \mathrm{kg}^{-1}$, Alyssum oxycarpum $1227.35 \mathrm{mg} \mathrm{kg}^{-1}$ (Çeliktaş, 2020), in Malatya Pb-Zn mine, Ni value Erysimum smyrnaeum $66 \mathrm{mg} \mathrm{kg}^{-1}$ was found (Kırat, 2009). The Ni values of all species in the Elazığ Maden District mining area were higher than the values specified by the researchers (Table 2 ). Normal limits for Fe concentration in plants have been reported as 2-250 $\mu \mathrm{g} . \mathrm{g}^{-1}$ (Yıldırım et al., 2012, Akgüç et al., 2010). In our study, Fe concentration was found within this limit.

According to the FAO / WHO (2003) standard, in plants the limit value is $30 \mathrm{mg} \mathrm{kg}^{-1}$. Permissible iron limit values in plants are reported to be between $50-150 \mathrm{mg} \mathrm{kg}^{-1}$ (Fergusson, 1990). Fe value is within the limit values in the soil and plants of the study area. Iron concentration values of Alyssum species collected around Adana chromium mine (Çeliktaş 2020) and iron concentration value of the species belonging to Glacium and Erysimum collected from Malatya Pb-Zn mine field Kırat (2017) were found higher than the Fe value of the species in our study (Table 3). Bioconcentration factors (BCF), transfer factors (TF), enrichment factors (EF) values and Geoaccumulation Index (Igeo) are summarized in table 4.

Table 3. According to various researchers, the limit values of fe in plants and soil and tukey's hsd test (means followed by the same letter are not significantly different at the 0.05 level /the first value is the lower limit of the contaminated value, the second value is the upper limit).

Çizelge 3. Çeşitli araştırmacılara göre bitkilerde ve toprakta Fe limit değerleri ve Tukey hsd testi (aynı harfin takip ettiği araçlar 0.05 düzeyinde önemli ölçüde farklı değildir / ilk değer kontamine değerin alt sınırıdır, ikinci değer üst sınırdır.).

\begin{tabular}{|c|c|c|c|c|}
\hline Species & Fe $(\mathrm{mg} / \mathbf{k g})$ & $\begin{array}{l}\text { Kabata-Pandias et } \\
\text { al. (1984) }\end{array}$ & $\begin{array}{l}\text { Allen } \\
(1989)\end{array}$ & $\begin{array}{l}\text { Istvan and } \\
\text { Benton (1997) }\end{array}$ \\
\hline A. leptophlla & $5.516 \pm 0.002 b$ & \multirow{4}{*}{$50-250$} & \multirow{4}{*}{$40-500$} & \multirow{4}{*}{500} \\
\hline A. pateri & $8.075 \pm 6.080 \mathrm{~b}$ & & & \\
\hline E. uncinatifolium & $42.106 \pm 0.338 a$ & & & \\
\hline \multirow[t]{2}{*}{ G. acutidentatum } & $6.386 \pm 0.004 b$ & & & \\
\hline & & $\begin{array}{l}\text { Kabata-Pandias } \\
\text { et.al. (1984) }\end{array}$ & $\begin{array}{l}\text { Adiloğlu } \\
\text { et.al. } \\
\text { (2011) }\end{array}$ & $\begin{array}{l}T_{K K Y^{*}} \\
(P h>6)(2001)\end{array}$ \\
\hline Soil & 4.424- 12.481 & 3800 & $\begin{array}{l}1.10- \\
22.55\end{array}$ & 4.5 \\
\hline
\end{tabular}


Kılıç and Ortakçı, Heavy Metal Accumulations in Some Terrestrial Endemic and Non-endemic Plants in Mine Sites (Elazığ/Turkey)

Table 4. BCF, TF, EF and IGEO values of the species.

Çizelge 4. Türlerin $B C F, T F, E F$ ve IGEO değerleri.

\begin{tabular}{lllllll}
\hline & Co & Ni & Fe & Co & Ni & Fe \\
& BCF & BCF & BCF & TF & TF & TF \\
\hline A. leptophlla & 1.256 & 1.076 & 1.140 & 11.907 & 26.562 & 21.119 \\
A. pateri & 7.256 & 0.198 & 0.333 & 22.174 & 3.595 & 12.169 \\
E. uncinatifolium & 2.095 & 2.030 & 7.184 & 0.612 & 14,411 & 13.462 \\
G. acutidentatum & 1.396 & 0.479 & 0.506 & 0.893 & 0.877 & 0.870 \\
& CoEF & Ni EF & FeEF & Co Igeo & Ni Igeo & Fe Igeo \\
A. leptophlla & 1.280 & 39.65 & 0.088 & 4.267 & 33.047 & 0.03 \\
A.pateri & 0.184 & 88.83 & 0.249 & 0.613 & 74.077 & 0.025 \\
E. uncinatifolium & 0.909 & 51.45 & 0.108 & 3.031 & 42.846 & 0.030 \\
G. acutidentatum & 0.637 & 40.32 & 0.110 & 2.125 & 33.635 & 0.025 \\
\hline
\end{tabular}

The higher BCF value, the more suitable it has been reported for phytoextraction of plants (Blaylock et al., 1997). BCF Values $>2$ were regarded as high values (Mellem et al., 2009). Zayed et al. (1998) divided the BCF into four categories; plants with $<0.01$ value is refer to non-accumulator feature, with 0.01-0.1 value a low accumulator, with 0.1-1.0 value medium accumulator, 1-10 are highly accumulative or hyperaccumulator plants. According to the Baker Theory used to evaluate the performance of plants used for phytoremediation, the plants are divided into 2 as good collectors and root holders. According to Baker's theory, a good collector plant is defined as a plant that can accumulate a high amount of elements in the aboveground parts. Accordingly, plants with the amount of elements accumulated in the above-ground parts higher than the amount of elements accumulated in their roots are classified as good collecting plants. Plants with this ratio lower than 1 are considered as plants (root holders) that do not transmit the elements they hold in their roots well to the shoot (Baker and Brooks, 1989).

By using this ratio, the absorption of the elements in the soil can be demonstrated and the size of the element transition from soil to the plant can be quantitatively estimated (Kalender and Alçiçek, 2016). Accordingly, it has been determined that all the studied species are highly accumulators. TF $>1$ is always essential in hyperaccumulator plants. TF is used to evaluate the capacity of transport metals from the roots of the plant to their upper organs. Accordingly, it was determined that Co element can be transported to upper organs in A. leptophlla, A. pateri species, $\mathrm{Ni}$ and Fe elements in A. leptophlla, A. pateri, E. uncinatifolium species. Enrichment occurs when a contaminant matter taken by a plant does not rapidly break down; resulting in plant accumulation. TF $>1$ indicates a very efficient ability to transport nutrients from roots to shoots, most likely due to efficient metal transport systems (Galal and Shehata, 2015). It is seen that all species are able to accumulate highly of $\mathrm{Ni}$ element from soil (Table 2).

Among the studied species, Co EF value in A. leptophlla and Ni EF value (EF> 1) in all species were higher than 1. It can be said that the $\mathrm{Ni}$ accumulation capacities of all species are high. In this study, EF values were found above 2. As the EF values increase, the contribution of the anthropogenic effect increases. EFs are generally evaluated using local background values. EF> 2 values refer to enriched samples (Mingorance et al., 2007).

Geoaccumulation index (Igeo), which makes pollution comparison before and after industry, is divided into 7 categories. Accordingly, Igeo $<0$ is not contaminated; $0<$ lgeo $<1$ Uncontaminated-moderately contaminated; 1 $<$ lgeo <2 Moderately contaminated; $2<$ lgeo $<3$ Moderate-heavily contaminated; $3<$ lgeo $<4$ Very contaminated; $4<$ Igeo $<5$ heavily contaminated; Igeo $>5$ It is classified as very heavily contaminated (Müller, 1969; Özkul et al., 2018). In this study, the soils taken from the study area according to the geoaccumulation index were found to be moderately contaminated in terms of Co and not so polluted in terms of Fe (Table 4).

\section{CONCLUSION}

In order for a plant to be a hyperaccumulator, it must be defined as plants capable of accumulating 100 times more metal than normal plants. A hyperaccumulator plant can absorb more than $10 \mathrm{ppm} \mathrm{Hg}$, more than $100 \mathrm{ppm} \mathrm{Cd}$, more than 1000 ppm Co, $\mathrm{Cr}, \mathrm{Cu}$, and $\mathrm{Pb}$ and more than 10,000 ppm Ni and $\mathrm{Zn}$ (Baker and Brooks, 1989). None of the studied types have been able to achieve 100-1000 times accumulation. All species are hyperacumulator according to CoBCF value. According to NiBCF and FeBCF values, A. leptophlla and E. uncinatifolium species were found to be hyperacumulators. According to TF value, It is determined that Co 
Kılıç and Ortakçı, Heavy Metal Accumulations in Some Terrestrial Endemic and Non-endemic Plants in Mine Sites (Elazığ/Turkey)

element can be transported upper organs in A. leptophlla, A. pateri species, whereas Ni and Fe elements in A. leptophlla, A. pateri, E. uncinatifolium species. Among the studied species, Co EF value in A. leptophlla and Ni EF value $(E F>1)$ in all species were higher than 1. It can be said that the Ni accumulation capacities of all species are high. this study, the soils taken from the study area according to the Igeo were found to be moderately contaminated in terms of Co and not so polluted in terms of Fe.

\section{CONFLICT OF INTEREST}

The authors declare that they have no conflict of interest.

\section{DECLARATION OF AUTHOR CONTRIBUTION}

Dudu Duygu Kılıç and Gülfiye Ortakçı field research, planning, design, analysis and experiment data analysis and writing the article.

\section{REFERENCES}

Adriano, D .C. (1986). Trace Elements in the Terrestrial Environment. Springer Verlag.

Akgüç, N., Özyiğit, I., Yaşar, U., Leblebici, Z., \& Yarcı, C. (2010). Use of Pyracantha coccinea Roem. as a possible biomonitor for the selected heavy metals. International Journal of Environmental Science Technology, 7(3), 427-434.

Aktan, M., Çimen, N., \& Özçelik, Y. (2017). Madencilik amaçlı orman izinlerinin Türkiye ve dünyadaki mevzuat uygulamalarının karşılaştırılması. Türkiye, 25th International Mining Congress and Exhibition of Turkey. Antalya, Turkey 25, 11-14.

Alaribe, F., \& Agamuthu, P. (2015). Evaluation of plant wetting potentials of Lantana camara in Pb affected soil with organic waste additives. Ecological Engineering, 83, 513-520.

Allen, S. E. (1989). Chemical Analysis of Ecological Materials. 2nd Edition, Blackwell Scientific Publications, Oxford and London.

Alloway, B. J. (1995). Cadmium. In B. J. Alloway (Ed.), Heavy metals in soils (pp. 283). Blackie, London.

Badr, N., Fawzy, M., \& Al Qahtani, K. M. (2012). Phytoremediation: An ecological solution to heavy-metal-polluted soil and evaluation of plant removal ability. WorldApplied Sciences Journal, 16(9), 1292-1301.

Baker, A. J. M., \& Brooks, R. (1989). Terrestrial higher plants which hyperaccumulate metallic elements. A review of their distribution ecology and phytochemistry. Biorecovery, 1(2), 81-126.

Bakırdede, S., Bölücek, C., \& Yaman, M. (2016) Determination of contamination levels of Pb, Cd, Cu, Ni, and Mn caused by former lead mining gallery. Environmental Monitoring and Assessment, 188(3), 132.

Becker, M., \& Asch, F. (2005). Iron toxicity in rice-conditions and management concepts. Journal of Plant Nutrition and Soil Science, 168(4), 558-573.

Blaylock, M. J., Salt, D. E., Dushenkov, S., Zakharova, O., Gussman, C., Kapulnik Y., \& Raskin, I. (1997). Enhanced accumulation of $\mathrm{Pb}$ in Indian mustard by soil-applied chelating agents. Environmental Science \& Technology, 31(3), 860865.

Borand, M. N. (2012). Açık ve kapalı maden işletmeciliğinde çevresel etki. İstanbul Teknik Üniversitesi Fen Bilimleri Enstitüsü, Madencilikte Özel Konular Ders Projesi, 61s.

Brooks, R. R. (1972). Geobotany and biogeochemistry in mineral exploration. New York: Harper \& Row.

Brooks, R. R., \& Radford, C. C. (1978). Nickel accumulation by European species of the genus Alyssum. Proceedings of the Royal Society of London, 200, 217-224.

Buat Menard, P., \& Chesselet, R. (1979). Variable influence of the atmospheric flux on the trace metal chemistry of oceanic suspended matter. Earth and Planetary Science Letters, 42, 399-411.

Cempel, M., \& Nikel, G. (2006). Nickel: a review of its sources and environmental toxicology. Polish Journal of Environmental Studies, 15(3), 375-382

Çakılcıoğlu, U., \& Civelek, S. (2011). Flora of the region between copper mine and Tekevler village (MadenElazig/Turkey). Biological Diversity and Conservation,4(1), 54-66.

Çeliktaş, V. (2020). Determination of phytoemediation properties of plants in chrome ore deposits in Aladağ district of Adana province. PhD thesis. Cukurova University, Adana, Turkey. 
Kılıç and Ortakçı, Heavy Metal Accumulations in Some Terrestrial Endemic and Non-endemic Plants in Mine Sites (Elazığ/Turkey)

Danh, L. T., Truong, P., Mammucari, R., Tran, T., \& Foster, N. (2009). Vetiver grass Vetiveria zizanioides: a choice plant for phytoremediation of heavy metals and organic wastes. International Journal of Phytoremediation, 11(8), 664-691.

Demir, Ö. (2018). Reflection of Mining Activities in Elazig to the Press of the Republican Era, Hiper Publishing, Istanbul, Turkey.

FAO/WHO. (2003). Codex Alimentarius International Food Standards Codex Stan-179,.Codex Alimentarius commission.

Fergusson, J. (1990). The heavy elements: Chemistry, environmental impact and health effects. New Zeland: Reader in Chemistry University of Canterbury Pergamon Press.

Galal, T. M., \& Shehata, H. S. (2015). Bioaccumulation and translocation of heavy metals by Plantago major L. grown in contaminated soils under the effect of traffic pollution. Ecological Indicators, 48, 244-251.

Garbisu, C., Hernandez-Allica, J., Barrutia, O., Alkorta, I., \& Becerril J. M. (2002). Phytoremediation: a technology using green plants to remove contaminants from polluted areas. Reviews on environmental health, 17, 75-90.

Guo ,Y. \& Marschner, H. (1995). Uptake distribution and binding of cadmium and nickel in different plant species. Journal of Plant Nutrition, 18(12), 2691-2706.

Hussain, M. B., Ali, S., Azam, A., Hina, S., Ahsan, M., Farooq, B. A., Bharwana, S. A., \& Gill, M. B. (2013). Morphological, physiological and biochemical responses of plants to nickel stress: a review. African Journal of Agricultural Research, 8(17), 1596-1602.

Jones, J. B. (1997). The Handbook of Trace Elements. Boca Raton, Florida: CRC Press.

Kacar B, Katkat V. (2006). Bitki Besleme. 1. Baskı. Nobel Yayın No:849, İstanbul.

Kacar, B., \& Katkat, V. (2010). Plant nutrition. 5th Edition, Nobel Yayın, Ankara.

Kalender, L., \& Alçiçek, Ö. N. (2016). Bioaccumulator Characteristics for Uranium and Thorium of Astragalus angustifolius, Artemisia ane Juncus effusus Firat University, Journal of Engineering Sciences, 28(2), 267-273.

Khan M. A. A., \& Siddhu, K. G. (2006). Phytotoxic effects of Cadmium (Cd) on Physiology of Urdbean [Vigna mungo (L.) Hepper.]. Advances in Plant Sciences, 19(2), 439-451.

Khan M. R., \& Khan, M. M. (2010). Effect of varying concentration of nickel and cobalt on the plant growth and yield of chickpea. Australian Journal of Basic and Applied Science, 4(6), 1036-1046.

Kırat, G. (2017). Pb - Zn - Cd Accumulator Plants Grown Around The Görgü Pb - Zn Mıne, Yeşilyurt-Malatya, Turkey. Bulletin of the Mineral Research and Exploration, 13(1), 53-63.

Ladislas, S., El-Mufleh, A., Gerente, C., Chazarenc, F., Andres, Y., \& Bechet, B. (2012). Potential of aquatic macrophytes as bioindicators of heavy metal pollution in urban stormwater runoff. Water Air and Soil Pollution, 223, 877-888.

Malaisse, F., Baker, A. J., \& Ruelle, S. (1999). Diversity of plant communities and leaf heavy metal content at Luiswishi copper/cobalt mineralization. Upper Katanga, Democratic Republic of the Congo,127, 3-16.

Mcgrath, S. P., Zhao, F. J., \& Lombi, E. (2001). Plant and rhizosphere processes involved in phytoremediation of metalcontaminated soils. Plant and Soil, 232, 207-214.

Mellem, J., Baijanth, H., \& Odhav, B. (2009). Translocation and accumulation of $\mathrm{Cr}, \mathrm{Hg}, \mathrm{As}, \mathrm{Pb}, \mathrm{Cu}$ and Ni by Amaranthus dubius (Amaranthaceae) from contaminated sites. Journal of Environmental Science and Health, 44, 568-575.

Mingorance, M. D., Valde'S, B., \& Oliva, S. R. (2007). Strategies of heavy metal uptake by plants growing under industrial emissions. Environment International, 33, 514-520.

Müller, G. (1969). Index of geo-accumulation in sediments of the Rhine River. Geo Journal, 2, 108-118.

Nawab, J. Khan, S., Shah, M. T., Khan, K., Huang, Q., \& Ali, R. (2015). Quantification of heavy metals in mining affected soil and their bioaccumulation in native plant species. International Journal of Phytoremediation, 17(9), 801-813.

Özbek, H., Kaya, Z., Gök, M., \& Kaptan, H. (1995). Toprak Bilimi. Çukurova Üniversitesi Ziraat Fakültesi Yayın No: 73, Adana.

Özkul, C., Acar, R. U., Köprübaşı, N., Er, A. E., Kızılkaya, H. İ., Metin, M., \& Şenel, M. N. (2018). Altıntaş (Kütahya Turkey) plain Investigation of heavy metal pollution in agricultural soil, preliminary studies. Journal of Applied Earth Sciences, 17(1), 1326.

Padmavathiamma, P. K., \& Li, L. Y. (2007). Phytoremediation technology: hyperaccumulation metals in plants. Water, Air and Soil Pollution, 184(1-4), 105-126.

Pourret, O., Lange, B., Bonhoure, J., Colinet, G., Decrée, S., Mahy, G., \& Faucon, M. P. (2016). Assessment of soil metal distribution and environmental impact of mining in Katanga. Applied Geochemistry, 64, 43-55.

Reeves, R. D., Baker, A. J., Jaffré, T., Erskine, P. D., Echevarria, G., \& Van der Ent, A. (2018). A global database for plants that hyperaccumulate metal and metalloid trace elements. New Phytologist, 218(2), 407-411. 
Kılıç and Ortakçı, Heavy Metal Accumulations in Some Terrestrial Endemic and Non-endemic Plants in Mine Sites (Elazığ/Turkey)

Reeves, R. D., \& Brooks, R. R. (1983). Hyperaccumulation of lead and zinc by two metallophytes from mining areas of Central Europe. Environmental pollution series A, Ecological and Biological, 31(4), 277-285.

Rose, A. W., Hawkes, H. E., \& Webb, J. S. (1979). Geochemistry in Mineral Exploration, second ed., Academic Press, Newyork, $657 \mathrm{~s}$.

Salt, D. E., \& Rauser, W. E. (1995). Mg ATP-Dependent Transport of phytochelatins across the tonoplast of oat roots. Plant Physiology, 107, 1293-1301.

Seeliger, T. C. Pernicka, E., Wagner, G. A., Begemann, E., Schimitt-Strecker, S., Eibner, C., Oztunali, O., \& Baranyi, I.(1985). Archaeometry of underground mining works of North and East Anatolia, Turkey. Jahrbuch des Römisch Germanischen Zentralmuseums (in German): Mainz.

Seregin, I. V., \& Kozhevnikova, A. D. (2006). Physiological role of nickel and its toxic effects on higher plants. Russian Journal of Plant Physiology, 53(2), 257-277.

Seven. T., Can, B., Darende, B. N., \& Ocak, S. (2018). Hava ve toprakta ağir metal kirliliği. Ulusal Çevre Bilimleri Araştırma Dergisi, 1(2), 91-103.

Shah, M. T., Begum, S., \& Khan, S. (2010). Pedo and biogeochemical studies of mafic and ultramfic rocks in the Mingora and Kabal areas, Swat, Pakistan. Environmental Earth Sciences, 60(5), 1091-1102.

Sibley, S. F. (2011). Overview of flow studies for recycling metal commodities in the United States (pp. AA1-AA25). Reston, VA: US Department of the Interior, US Geological Survey.

Şengün, M. T. (2007). The effect of Keban Dam Lake to Elazığ climate under the last valuations light. Journal of Research of Eastern Anatolia Region, 5, 116-121.

Tok, Ç. (1997). Environmental pollution. Anadolu Printing, Istanbul.

Van Der Ent, A., Echevarria, G., \& Tibbett, M. (2016). Delimiting soil chemistry thresholds for nickel hyperaccumulator plants in Sabah (Malaysia). Chemoecology, 26(2), 67- 82.

Yang, X. E., Long, X. X., Ye, H. B., He, Z. L., Calvert, D. V., \& Stoffella, P. J. (2004). Cadmium tolerance and hyperaccumulation in a new Zn-hyperaccumulating plant species (Sedum alfredii Hance). Plant and Soil, 259(1-2), 181-189.

Yanqun, Z., Yuan, L., Jianjun, C., Haiyan, C., Li, Q., \& Schvartz, C. (2005). Hyperaccumulation of Pb, Zn and Cd in herbaceous grown on lead-zinc mining area in Yunnan, China. Environment International, 31(5), 755-762.

Yerli C, Çakmakcı T, Şahin Ü, Tüfenkçi Ş. (2020). Ağır metallerin toprak, bitki, su ve insan sağlığına etkileri. Türk Doğa ve Fen Dergisi, 9(Özel Sayı), 103-114.

Yıldırım, C., Karavin, N., \& Cansaran, A. (2012). Elaeagnus angustifolia L and Pinus brutia Ten in Amasya city center. Determination of the content of some heavy metals in their types. Journal of Biological Sciences Research, 5(2), 7-11.

Zayed, A., Lytle, C. M., Qian, J. H., \& Terry, N. (1998). Chromium accumulation, translocation and chemical speciation in vegetable crops. Planta, 206(2), 293-299. 